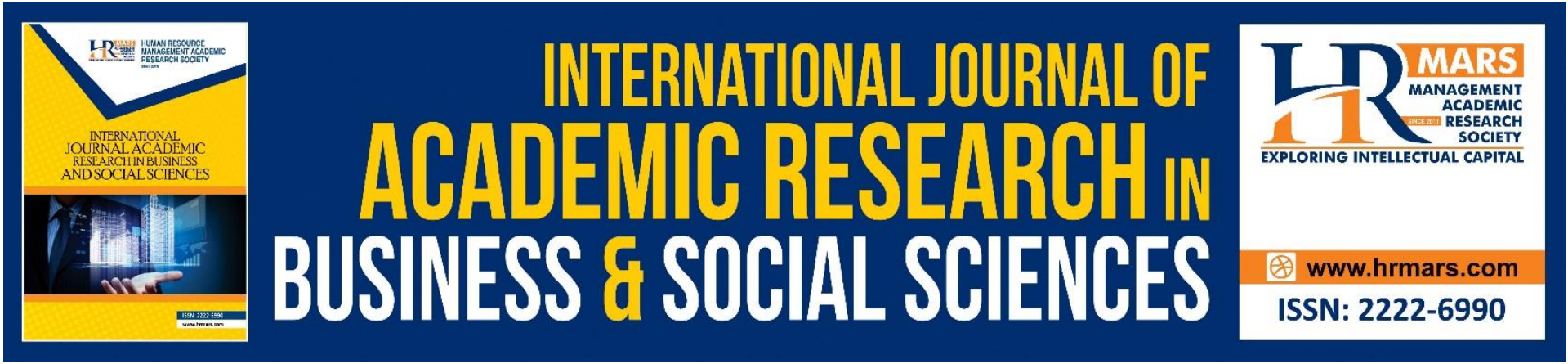

\title{
Authentic Learning though Role Play in Learning Financial Reporting: Malaysian Undergraduate Perspective
}

\author{
Damien Lee, Sharon Cheuk and Esmie Nichol
}

To Link this Article: http://dx.doi.org/10.6007/IJARBSS/v10-i8/7500

DOI:10.6007/IJARBSS/v10-i8/7500

Received: 28 May 2020, Revised: 24 June 2020, Accepted: 20 July 2020

Published Online: 19 August 2020

In-Text Citation: (Lee et al., 2020)

To Cite this Article: Lee, D., Cheuk, S., \& Nichol, E. (2020). Authentic Learning Though Role Play in Learning Financial Reporting: Malaysian Undergraduate Perspective. International Journal of Academic Research in Business and Social Science, 10(8), 42-58.

Copyright: (C) 2020 The Author(s)

Published by Human Resource Management Academic Research Society (www.hrmars.com)

This article is published under the Creative Commons Attribution (CC BY 4.0) license. Anyone may reproduce, distribute, translate and create derivative works of this article (for both commercial and non-commercial purposes), subject to full attribution to the original publication and authors. The full terms of this license may be seen

at: http://creativecommons.org/licences/by/4.0/legalcode

Vol. 10, No. 8, 2020, Pg. 42 - 58

http://hrmars.com/index.php/pages/detail/IJARBSS

JOURNAL HOMEPAGE

Full Terms \& Conditions of access and use can be found at http://hrmars.com/index.php/pages/detail/publication-ethics 


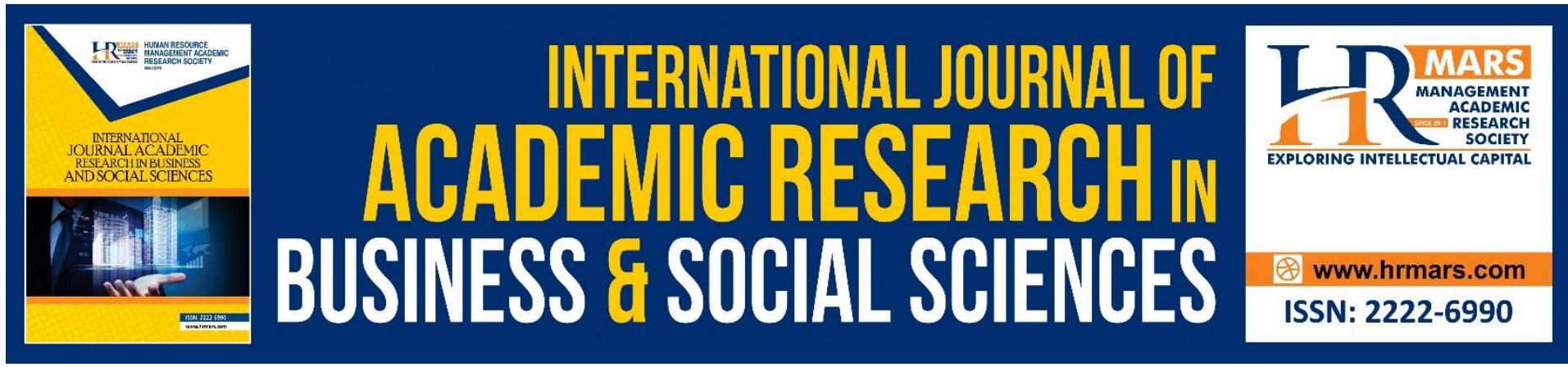

\title{
Authentic Learning Though Role Play in Learning Financial Reporting: Malaysian Undergraduate Perspective
}

\author{
Damien Lee, Sharon Cheuk and Esmie Nichol \\ Faculty of Economics and Business, Universiti Malaysia Sarawak, 94300 Kota Samarahan, \\ Sarawak, Malaysia \\ Email: liydamien@unimas.my
}

\begin{abstract}
This paper examines whether role-playing provides student with learning opportunities in financial reporting and motivates student to reflect the practical financial reporting issues. The research is conducted in Advance Financial Reporting class under an undergraduate accounting program in a public university during semester two in 2019. The participants were divided into two roles within the context of an audit firm, audit associate and audit supervisor in preparing and reviewing the consolidation of financial statements audit working paper (financial reporting). The results of the study show that role-playing allowed students to improve their knowledge and increase their confidence in preparing consolidated financial statements. It also motivates student to reflect the practical financial reporting issues. Hence, the results suggest that role-play model can be applied to other accounting learning activities with inter-related subjects within accounting.
\end{abstract}

Keywords: Authentic Learning, Role Play, Financial Reporting, Auditing, Undergraduate, Malaysia.

\section{Introduction}

The Accounting study is regarded as a dry and requires high learning concentration subject, which can stress up both teachers and students (Buckhaults \& Fisher, 2011). The stress can affect the teaching delivery quality and learning effectiveness among the teachers and students. Contemporary and innovative teaching approaches are vital to engaged students and facilitate them to learn (Samkin \& Stainbank, 2016). Further, an effective accounting education transformation can bring accounting course closer to the real business world (Boyce, 2004). Therefore, supplement the accounting study with alternative learning method, such as authentic learning methodology can provide students with more learning opportunities beside traditional classroom interactions.

Accounting education literature's statistic has recorded Asia region contributed $6 \%$ of total six established accounting education journals published between 1997 to 2016 (Apostolou, et al., 2017). Further, Tan, et al. (2014) suggests that authentic learning approach can develop high-order thinking among students, which is in line with the Malaysian National Higher 
Education Strategic Plan 2011-2015. The continuing Malaysian higher education document, Malaysia Education Blueprint 2015-2025 planned to improve students' learning experience by incorporating industry input into delivery academic curriculums and prepare them for $21^{\text {st }}$ century work readiness (Ministry of Education Malaysia, 2015). Kilgour, et al. (2015) suggests scenario based role-play with predetermined learning outcome can provide real life experiential learning among students. On the same vein, authentic learning methodology allowed students to link the concepts and theories to the practical world (Hui \& Koplin, 2011). These articles and Malaysian education plans has motivated us to investigate whether authentic learning offers student learning opportunities in the context of accounting education at tertiary level in Malaysia, particularly financial reporting.

Kilgour, et al. (2015) studied role-playing in teacher education, for the subjects of history, primary mathematics and education leadership. They found that role-play activities facilitate active learning in history, changes student perception about mathematics and mathematics teaching, and stimulates leadership learning. Besides teacher education, Hui \& Koplin (2011) research on authentic learning among $3^{\text {rd }}$ year International Finance subject taken by Australian students, and discovered that it helps student to connect the classroom learning to the real world, and allowed students to comprehend better the finance issues arises from continuous environment change.

There are few authentic learning studies conducted in Malaysia. Neo, et al. (2012) found that authentic learning environment allow Malaysian students do well in their Interactive Multimedia project. Similarly, Tan, et al. (2014) discovered authentic learning with the help of multimedia and web tools can develop Malaysian Digital Media students' creative and critical thinking skills. Another Malaysian research found that students are more engaged and involved in learning Interactive Multimedia subject when they are in authentic blended learning environment (Tan \& Neo, 2015). Toh, et al. (2012) also discovered authentic learning promote team work, creativity and active learning among Malaysian final year English Bachelor degree students. Likewise, Husnin, et al. (2013) authentic activity has created a positive learning environment by nurturing meaningful learning among English trainee teachers in Malaysia.

Saptono (2010) uses role-play model (part of the authentic learning methodology) in improving Indonesian students learning satisfactions and their scores in Financial Accounting. On the same notion, O'Callaghan et al. (2012) utilises role-play approach in introducing American students to Auditing. Based on the literature reviewed, the studies conducted in overseas and Malaysia focuses teachers' education in various subjects, finance, digital/interactive multimedia, accounting subjects. However, no research investigating the role of authentic learning in the area of accounting education, specifically financial reporting. Hence, financial reporting authentic learning research is relevant and timely in line with Malaysia higher education plan.

We extent prior works in authentic learning and accounting education to a broader accounting authentic learning literature in financial reporting. This study aims to investigate these two research questions:

i. Does role-playing provides student with learning opportunities in financial reporting?

ii. Does role-playing motivates student to reflect the practical financial reporting issues? 
The remainder of this paper is organised as follows. The next section (Section 2) provides an overview of tertiary education, particularly types and nature of authentic learning. In section 3 , we discuss the research method, the preparation and setting of our role-play activities. It followed by results and discussions in Section 4, and students' evaluation of role play activities in Section 5. The final section (Section 6) is the conclusions of the study.

\section{Literature Review}

Learning by doing is one of the effective ways for student to learn in tertiary education. Certain students prefer to learn through practice rather than solely relying on class teaching (Lombardi, 2007). Further, 'Active learning' such as role-play allows student to do deep learning by helping them to remember the fact and grapping concept better (Kilgour, et al., 2015). Similarly, de Araujo \& Slamski (2013) suggests active learning can improve students' learning process and their analysis on the education literatures reveals this learning method is more effective than conventional teaching methods. Active learning also provides students with more learning space by offering them more interactive sessions through various educational activities (Saptono, 2010).

On the same vein, academicians opined that each individual student learn differently, variety of teaching strategies can assist them in learning; particularly accounting students tend to be submissive in the class (Saptono, 2010). The development of a range of education tools offers student with more authentic learning opportunities include role-playing, service based learning etc. Role-playing has been use for academic delivery for long time focuses wider group methods in applying into simulation and gaming activities emphasized on student interactions under different education settings (Craign \& Amernic, 1994). The nature of authentic learning involves elements: activities reflecting practical scenarios, undertake learning in a meaningful way in the context of real world, and instruction focuses on learner (Rule, 2006). Lombardi (2007) provides the following examples of authentic learning and its benefits.

Table 1: Summary of types of authentic learning with its application and benefits

\begin{tabular}{|l|l|l|}
\hline $\begin{array}{l}\text { Types of authentic } \\
\text { learning }\end{array}$ & Application description & Benefits \\
\hline Simulation-Based Learning & $\begin{array}{l}\text { uses simulation and role-playing } \\
\text { to immerse students in the } \\
\text { complexities of authentic } \\
\text { decision making in online } \\
\text { learning environment for } \\
\text { engineering projects }\end{array}$ & $\begin{array}{l}\text { help students to develop their } \\
\text { communication, } \\
\text { collaboration, and leadership } \\
\text { skills, which they will need to } \\
\text { be successful practitioners in } \\
\text { their fields }\end{array}$ \\
\hline Student-Created Media & $\begin{array}{l}\text { created 3D virtual } \\
\text { reconstructions of the ancient } \\
\text { Athenian marketplace known as } \\
\text { the agora and were required to } \\
\text { present a rationale for the } \\
\text { design choices they made as } \\
\text { they built their replicas of the } \\
\text { agora's theater, museum, and } \\
\text { mint }\end{array}$ & $\begin{array}{l}\text { Ancient Spaces 3D model } \\
\text { doing ore able to learn by } \\
\text { learn by reconstructing key } \\
\text { architectural and artistic } \\
\text { environments of the ancient } \\
\text { world }\end{array}$ \\
\hline
\end{tabular}




\begin{tabular}{|c|c|c|}
\hline Inquiry-Based Learning & $\begin{array}{l}\text { cognitive scientists are teamed } \\
\text { with expert faculty in a variety of } \\
\text { disciplines to reach an } \\
\text { understanding of where novices } \\
\text { commonly run into trouble when } \\
\text { introduced to unfamiliar } \\
\text { material in a particular field }\end{array}$ & $\begin{array}{l}\text { the teams design Web-based } \\
\text { courses that are "cognitively } \\
\text { guided," providing students } \\
\text { with the scaffolding they } \\
\text { need at every stage of their } \\
\text { development as pre } \\
\text { professionals }\end{array}$ \\
\hline Peer-Based Evaluation & $\begin{array}{l}\text { free Web-based program that } \\
\text { allows instructors to incorporate } \\
\text { frequent writing assignments } \\
\text { into their courses, regardless of } \\
\text { class size, without increasing } \\
\text { their grading workload }\end{array}$ & $\begin{array}{l}\text { Students are trained to be } \\
\text { competent reviewers and are } \\
\text { then given the responsibility } \\
\text { of providing their classmates } \\
\text { with personalized feedback } \\
\text { on expository writing } \\
\text { assignments }\end{array}$ \\
\hline $\begin{array}{l}\text { Working with Remote } \\
\text { Instruments }\end{array}$ & $\begin{array}{l}\text { University makes it possible for } \\
\text { students around the world to } \\
\text { conduct experiments with } \\
\text { specialized equipment located } \\
\text { on its campus, including a shake } \\
\text { table that simulates earthquakes } \\
\text { and a sensor-equipped flagpole } \\
\text { that measures meteorological } \\
\text { parameters }\end{array}$ & $\begin{array}{l}\text { this learning approach can } \\
\text { open the door to active } \\
\text { learning experiences that } \\
\text { would otherwise be beyond } \\
\text { their reach }\end{array}$ \\
\hline $\begin{array}{l}\text { Working with Research } \\
\text { Data }\end{array}$ & $\begin{array}{lrr}\text { students are } & \text { becoming } \\
\text { legitimate } & & \text { peripheral } \\
\text { participants } & \text { in } & \text { virtual } \\
\text { communities of } & \text { practice, } \\
\text { collecting data either first-hand } \\
\text { or through remotely located } \\
\text { smart sensors }\end{array}$ & $\begin{array}{l}\text { students are practicing } \\
\text { higher-order analysis on real } \\
\text { data sets while contributing } \\
\text { to the common knowledge } \\
\text { base }\end{array}$ \\
\hline $\begin{array}{l}\text { Reflecting } \quad \text { and } \\
\text { Documenting } \\
\text { Achievements }\end{array}$ & $\begin{array}{l}\text { the mechanical engineering } \\
\text { faculty at a University needed a } \\
\text { way of documenting and sharing } \\
\text { student projects, tracking the } \\
\text { achievement of learning } \\
\text { objectives, reinforcing the link } \\
\text { between class work and real- } \\
\text { world engineering concerns, and } \\
\text { encouraging students to reflect } \\
\text { on their own learning processes }\end{array}$ & $\begin{array}{l}\text { students not only use their e- } \\
\text { portfolios to showcase their } \\
\text { best work and evaluations for } \\
\text { prospective employers; it also } \\
\text { supports the learning process }\end{array}$ \\
\hline
\end{tabular}

Source: (Lombardi, 2007, p. 4 - 6)

The above table highlights that role-play through online learning environment can help the students to build their communication, teamwork and leadership skills. On the same notion, Saptono (2010) documented that role-play could improve students' learning process by increasing their positiveness towards the university and the subject studied, as well as educators, when they are encouraged to work collaboratively with other students. Similarly, 
O'Callaghan et al. (2012) found that role-play allow student to understand auditing environment better in the perspectives of sources of evidence, differences between internal and external evidence, and evidence evaluation.

\section{Research Methodology}

Objectives of role-play

The research was conducted in Advanced Financial Reporting class under an undergraduate accounting program offered by a public university in Kota Samarahan, Sarawak. The role-play exercise was carried out during second last week of semester two in 2019 with the following objectives:

- to allow student to apply their group accounts knowledge in the scenario given;

- to work collaboratively with other students (before they write their own reflection);

- to understand the auditor's role in the context of an audit firm; and

- allow student to explore the application of group account skills in the context of audit firm's organisation role.

This exercise aims to enhance student experiential learning in the practical financial reporting within accountant's public practice setting. The role-play exercise sets in the context of an audit firm to allowed student to explore group accounts preparation in financial reporting, and at the same time exposed students to the subject of auditing with the roles of external auditor, namely audit associate and audit supervisor. Since the students are taking first unit of auditing during the semester concurrently with the financial reporting unit (covering group accounts) in the accounting program, hence the role-play scenario can add value to the students' learning by linking them to both areas of financial reporting and auditing through preparation of group accounts in an audit firm scenario.

\section{Preparation and Instruction}

Students have been informed that there will be a role-play exercise two weeks before hand. They have some basic idea that the role-play is in the context of group account preparation, but they didn't know exactly it is in the context of an audit firm. Before the role-play begins, the students were brief about the role of auditor in audit public practice scenario, where there are several different roles in an audit firm including audit associate/assistant, audit senior, audit supervisor/manager and audit partner. They were explained in detailed manner pertain the roles that they are going to play, namely the audit associate and audit supervisor with the help of exercise information handout. The case of the consolidation account is about midyear partial acquisition of a subsidiary with fair value measurement for non-controlling interest. Simple Statement of Financial Position figures were involved to ensure students focused on the concept rather than figures complication.

\section{Participants and Tasks}

There were 65 students took part in this role-play exercise. The students are divided into two groups, namely group $A$ is playing the role of audit associate, and group B is playing the role as audit supervisor. There are 34 students in group $A$ and 31 students in group B. Students in group $A$ are supposed to prepare group accounts audit working paper of an audit firm, and later they will pass their audit working paper to their peers (in group B) who act as audit supervisor for review. The students in group A were assigned to calculate the goodwill on consolidation and preparation the relevant consolidation journal entries related to the 
elimination of investment in a subsidiary. Then, the students were tasked to review the correctness of the consolidation goodwill calculation and consolidation journal entries pertains to it. However, the accuracy of the group accounts audit working paper preparation and its review are not the focus of this exercise, but the emphasis on students' experiential learning in financial reporting in the context of auditing firm's operation through student reflections after the role-play activities. Students were from various ethics background and have the following gender profile. The accounting program has higher intake for female compared with its male counterpart. These statistics reflect the figures released by Malaysian Ministry of Higher Education, where 65 percent of universities intake each year were females (Zandi, et al., 2013). This fact further translates into the accountant professional membership in Malaysia, where 59 percent of The Association of Chartered Certified Accoutants' (ACCA) professional members in Malaysia are female (ACCA, 2018).

Table 2: Summary of students' gender profile

\begin{tabular}{|c|c|c|}
\hline Group & A & B \\
\hline Male & $11(32.4 \%)$ & $8(25.8 \%)$ \\
\hline Female & $23(67.6 \%)$ & $23(74.2 \%)$ \\
\hline
\end{tabular}

This role-play exercise is under the supervision of two accounting lecturers for students to make any clarifications if needed. This reflective role-play exercise took approximately 40 mins for each group, involving students in group A to prepare the group accounts audit working paper and writing their reflections; whereas students in group $B$ reviewed the drafted audit working paper (prepared by group $A$ ) and writing their reflections on their roles given. The tasks for groups A and B detailed are as follow:-

Table 3: Summary of tasks assigned to students in groups A and B

\begin{tabular}{|c|l|l|}
\hline Task & Group A (audit associate) & Group B (audit supervisor) \\
\hline 1 & $\begin{array}{l}\text { Prepare audit working paper for the goodwill } \\
\text { on consolidation and its relevant consolidation } \\
\text { journal entries pertain to the elimination of } \\
\text { investment in subsidiary. }\end{array}$ & $\begin{array}{l}\text { Review on the working paper of the } \\
\text { correctness of the audit working paper } \\
\text { (prepared by your audit associate/assistant) } \\
\text { pertain to goodwill on consolidation and its } \\
\text { consolidation journal entries pertain to the } \\
\text { elimination of investment in subsidiary. }\end{array}$ \\
\hline 2 & $\begin{array}{l}\text { Reflection }: \text { Describe what is your } \\
\text { consolidation/group account knowledge and } \\
\text { confidence before doing this role play } \\
\text { exercise? }\end{array}$ & $\begin{array}{l}\text { Reflection : Describe what is your } \\
\text { consolidation/group account knowledge and } \\
\text { confidence before doing this role play } \\
\text { exercise? }\end{array}$ \\
\hline 3 & $\begin{array}{l}\text { Reflection : What knowledge and experience } \\
\text { you have gain from this audit } \\
\text { associate/assistant role play exercise? (You can } \\
\text { reflect from the perspectives of knowledge } \\
\text { gain/re-enforcement, experience of drafting } \\
\text { audit working paper, application of your } \\
\text { technical skill, self confidence in preparation of } \\
\text { group account after this exercise or other } \\
\text { perspectives) }\end{array}$ & $\begin{array}{l}\text { Reflection : What knowledge and experience } \\
\text { play exercise? (You can reflect from the } \\
\text { perspectives of knowledge gain/re- } \\
\text { enforcement, experience when review the } \\
\text { audit working paper, application of your } \\
\text { technical skill, self confidence in preparation } \\
\text { of group account after this exercise or other } \\
\text { perspectives) }\end{array}$ \\
\hline
\end{tabular}

There were 65 students participated in this study where 34 of them are in group A, playing audit associate role and 31 of them are in group $B$, playing the role as audit supervisor. Table 
4 shows the he responses usability for both groups. Six of the responses for group $A$ are unusable leaving 28 responses unusable, and 11 responses from group $B$ unusable, giving 20 responses left usable, as depicted in Table 4.

Table 4: Participants' usable response

\begin{tabular}{|l|c|c|}
\hline Group & A & B \\
\hline Responses received & 34 & 31 \\
Unusable responses & $(6)$ & $(11)$ \\
\hline Usable responses & 28 & 20 \\
\hline
\end{tabular}

\section{Results and Discussions}

The student reflections on the role that they played are summarized in Table 5 for group $A$, audit associate and Table 6 for group B, audit supervisor.

Table 5: Summary of Groups A's reflections (audit associate)

\begin{tabular}{|c|c|c|}
\hline No. & $\begin{array}{l}\text { Describe what is your } \\
\text { consolidation/group account knowledge } \\
\text { and confidence before doing this role play } \\
\text { exercise? }\end{array}$ & $\begin{array}{l}\text { What knowledge and experience you } \\
\text { have gain from this audit } \\
\text { associate/assistant role play exercise? }\end{array}$ \\
\hline 1 & $\begin{array}{l}\text { ".... not confidence before doing this role } \\
\text { play exercise..." }\end{array}$ & $\begin{array}{l}\text { ".. I am still scared that I missed some } \\
\text { information ..." }\end{array}$ \\
\hline 2 & $\begin{array}{l}\text { ".... not confidence on doing consolidation } \\
\text { or group account..." }\end{array}$ & $\begin{array}{l}\text { ".. get some idea on what is the task of } \\
\text { audit assistant and audit supervisor."; "... } \\
\text { learn that every information about the } \\
\text { account should be clearly stated as an } \\
\text { evidence."; "... get a clear picture on pre } \\
\text { and post acquisition."; ".... still not very } \\
\text { confidence ....." }\end{array}$ \\
\hline 3 & $\begin{array}{l}\text { ".... knowledge before doing this role play } \\
\text { exercise is moderate ..." }\end{array}$ & $\begin{array}{l}\text { "... gain knowledge on the part that I am } \\
\text { lack of from other colleague ..."; “.... } \\
\text { experience that I gain while working on } \\
\text { audit working paper is valuable....."; “... I } \\
\text { have gain more confidence....." }\end{array}$ \\
\hline 4 & $\begin{array}{l}\text { ".. not confident enough ..."; "I have rough } \\
\text { idea on how to calculate goodwill ....." }\end{array}$ & $\begin{array}{l}\text { "... my knowledge on the group account } \\
\text { increase ..."; "I am confident enough to } \\
\text { compute ....." }\end{array}$ \\
\hline 5 & $\begin{array}{l}\text { ".... not confident enough ..."; "There are } \\
\text { few things that I am not sure ....." }\end{array}$ & $\begin{array}{l}\text { "In have gain some assurance regarding } \\
\text { group/consolidated account"; "The } \\
\text { discussion with follow peers"; “... able to } \\
\text { reinforce my understanding ......"; "I } \\
\text { become more confidence.......". }\end{array}$ \\
\hline 6 & $\begin{array}{l}\text { ".... my knowledge to do consolidation is } \\
\text { not good ... is confusing ....."; ".... was } \\
\text { difficult for me ...." }\end{array}$ & $\begin{array}{l}\text { "After discuss with my group, ..... the } \\
\text { consolidation is not difficult ......."; “.... } \\
\text { confidence in making the reporting } \\
\text { improve ......" }\end{array}$ \\
\hline 7 & $\begin{array}{l}\text { ".... knowledge still need to improve."; "My } \\
\text { confidence level is at average" }\end{array}$ & $\begin{array}{l}\text { “.... knowledge in doing consolidation ..... } \\
\text { become better ..... with the help from my }\end{array}$ \\
\hline
\end{tabular}




\begin{tabular}{|c|c|c|}
\hline & & $\begin{array}{l}\text { friends."; “.... Improve my confidence } \\
\text {......" }\end{array}$ \\
\hline 8 & $\begin{array}{l}\text { ".... little bit of knowledge and less } \\
\text { confidence ......" }\end{array}$ & $\begin{array}{l}\text { "After this role play exercise, I have gain } \\
\text { more understanding ......" }\end{array}$ \\
\hline 9 & $\begin{array}{l}\text { ".. little bit of knowledge and not } \\
\text { confidence ......." }\end{array}$ & $\begin{array}{l}\text { ".... I have learn from my peers ......; .... it } \\
\text { helps me to enhance myself } \\
\text { confidence......." }\end{array}$ \\
\hline 10 & “.... I am still confused ........" & $\begin{array}{l}\text { ".... gain more knowledge through my } \\
\text { colleague ......; ..... confidence in } \\
\text { preparation of group account has } \\
\text { increased ......." }\end{array}$ \\
\hline 11 & $\begin{array}{l}\text { ".. my knowledge about } \\
\text { consolidation/group account is low and not } \\
\text { confident ......."; ".... still confuse ......" }\end{array}$ & $\begin{array}{l}\text { ".... I have gain more knowledge ......; ..... I } \\
\text { also feel more confident ......." }\end{array}$ \\
\hline 12 & $\begin{array}{l}\text { "... not confident ......."; "..... I still need to } \\
\text { refer to the note ......" }\end{array}$ & $\begin{array}{l}\text { ".... make me more understand ......; ..... } \\
\text { gain my confidence ......." }\end{array}$ \\
\hline 13 & $\begin{array}{l}\text { "... knowledge and confidence ....... were } \\
\text { quite low." }\end{array}$ & $\begin{array}{l}\text { " ...... did not help me much to improve } \\
\text { knowledge and confidence ........." }\end{array}$ \\
\hline 14 & $\begin{array}{l}\text { "... knowledge and confidence ....... were } \\
\text { low."; "I am a bit confuse ............" }\end{array}$ & $\begin{array}{l}\text { "...... has slightly help to improve my } \\
\text { knowledge and confidence ........." }\end{array}$ \\
\hline 15 & $\begin{array}{l}\text { ".... barely differentiate the method of } \\
\text { goodwill calculation ......." }\end{array}$ & $\begin{array}{l}\text { "... now I can determine the method of } \\
\text { goodwill calculation......." }\end{array}$ \\
\hline 16 & $\begin{array}{l}\text { "... knowledge and confidence } \ldots . . . \text { at } \\
\text { average level." }\end{array}$ & $\begin{array}{l}\text { “.... enhances my knowledge ........"; “I am } \\
\text { more confidence now ............."; “...... } \\
\text { aware of proper information } \\
\text { presentation for user to understand ....." }\end{array}$ \\
\hline 17 & $\begin{array}{l}\text { "... slight understanding on consolidation } \\
\text { account knowledge ......"; “.... a bit } \\
\text { confidence ......" }\end{array}$ & $\begin{array}{l}\text { " .... it helps to re-enforce my knowledge } \\
\text {......"; "...... aware of proper presentation } \\
\text { of audit working paper is essential ....." }\end{array}$ \\
\hline 18 & $\begin{array}{l}\text { "... knowledge and confidence is } \\
\text { moderate." }\end{array}$ & $\begin{array}{l}\text { " .... it helps to re-enforce my knowledge } \\
\ldots . . . " ; " . . . . . \text { gained self confidence ....." }\end{array}$ \\
\hline 19 & "I have a lot of confidence ......." & $\begin{array}{l}\text { “.... I have gained more confidence ......."; } \\
\text { “..... reinforce my knowledge ....."; “..... } \\
\text { gain experience on how to draft an audit } \\
\text { working paper ........." }\end{array}$ \\
\hline 20 & $\begin{array}{l}\text { "... really take time for me to start my } \\
\text { consolidated account." }\end{array}$ & $\begin{array}{l}\text { ".... I have learned .... goodwill value from } \\
\text { the investment ......" }\end{array}$ \\
\hline 21 & $\begin{array}{l}\text { "... learning group account is quite tough } \\
\text { for me." }\end{array}$ & $\begin{array}{l}\text { "... gained some knowledge and } \\
\text { experience from this audit } \\
\text { associate/assistant role ...."; "I am having } \\
\text { fun doing this role play exercise ......" }\end{array}$ \\
\hline 22 & $\begin{array}{l}\text { ".... do not understand much about } \\
\text { consolidation/group ......" }\end{array}$ & $\begin{array}{l}\text { ".... I get to know how to calculate the } \\
\text { goodwill."; ".... I must calculate in detail } \\
\text { to make sure the supervisor understand } \\
\text { it...." }\end{array}$ \\
\hline 23 & ".... I have little knowledge ......." & $\begin{array}{l}\text { " .... I manage to gain more knowledge .... } \\
\text { through discussion with my peer.”; “.... I }\end{array}$ \\
\hline
\end{tabular}




\begin{tabular}{|c|c|c|}
\hline & & $\begin{array}{l}\text { also manage to increase self } \\
\text { confidence....." }\end{array}$ \\
\hline 24 & $\begin{array}{l}\text { ".... I never knew about group accounts."; } \\
\text { ".... a difficult topic to learn." }\end{array}$ & $\begin{array}{l}\text { ".... able to gain more knowledge ....."; } \\
\text { ".... able to apply all my knowledge that I } \\
\text { have gained from classes...." }\end{array}$ \\
\hline 25 & $\begin{array}{l}\text { ".... moderate level of confidence......."; ".... } \\
\text { still have a bit of confusion......"; "I have } \\
\text { lack of ability to determine the amount } \\
\text {............" }\end{array}$ & $\begin{array}{l}\text { "... knowledge on group account had } \\
\text { increase....."; ".... able increase my } \\
\text { confidence...." }\end{array}$ \\
\hline 26 & $\begin{array}{l}\text { "My knowledge is still moderate while my } \\
\text { confidence is still low, ........."; "..... still } \\
\text { struggle to understand the concept ........." }\end{array}$ & $\begin{array}{l}\text { " .... manage to re-enforce my } \\
\text { knowledge....."; "My self confidence in } \\
\text { preparing group account increases ...." }\end{array}$ \\
\hline 27 & $\begin{array}{l}\text { "The knowledge and confidence about } \\
\text { group account is very low .... find this } \\
\text { chapter is very difficult." }\end{array}$ & $\begin{array}{l}\text { ".... I can relate to what I have learn....."; } \\
\text { "... can help me to imagine the real } \\
\text { situation of audit ......"; "My self } \\
\text { confidence in preparation of group } \\
\text { account increases...." }\end{array}$ \\
\hline 28 & $\begin{array}{l}\text { ".... lack of knowledge on how to start the } \\
\text { consolidation ......." }\end{array}$ & $\begin{array}{l}\text { “... good experience to be an audit } \\
\text { assistant." }\end{array}$ \\
\hline
\end{tabular}

10 participants in Group A playing the role of audit associate has indicated that their knowledge about consolidation accounts is either low, not good, little, slight or lack, with one participant never knew about group accounting. There are four participants in this group have moderate knowledge pertain to consolidation, while one participant do not understand much about it. Eight out of the 10 participants in first category have experienced some learning after this role-play exercise by gaining more understanding/knowledge, found consolidation of account is not difficult after all, help slightly to improve knowledge, helps to re-enforce knowledge and assist in linking to prior class learning (three of them learned through group or peer discussions), with one participant did not experience much learning. On the same notion, one participant who never knew about group account has experienced more knowledge gain. Similarly, all the four students who have moderate knowledge also found this exercise improved, enhanced and re-enforced their knowledge, and one student who do not have much understanding about group accounting learned how to calculate goodwill on consolidation.

There are 13 students in group A who have either no, less, low or a bit of confidence in preparing group accounting before doing this role-play. On the other hand, there are four students who have either average or moderate confidence level in doing consolidation accounts and one student who has high of confidence. Nine out of 13 students felt that their confidence level improved after doing this role-play exercise, with one student who felt their confidence does not change much. On the same vein, the other students who have moderate and high confidence level also found their confidence increase after this exercise.

Beside gaining some knowledge and confidence in preparation of group accounts, this roleplay allows student to get some idea of the role of auditors, particularly audit associate and audit supervisor. It also makes student to reflect about the audit evidence issue. Two students have gained some valuable experience in preparing draft audit working paper, while the other 
two students reflected the importance of proper presentation of information in audit working paper. One student is having "fun" in doing the role of audit associate and another student felt that information presented must be understandable by their superior, audit supervisor. This activity also helps one student to imagine the real world of auditing.

Collectively, most of the students have experienced some improvement in their knowledge or/and confidence in consolidation accounts topic. On top of this, the role-play exercise has given opportunities for students to reflect the real practical auditing scenario in the context of auditor's role, evidence, information and audit working paper.

Table 6: Summary of Groups B's reflections (audit supervisor)

\begin{tabular}{|c|c|c|}
\hline No. & $\begin{array}{l}\text { Describe what is your } \\
\text { consolidation/group account knowledge } \\
\text { and confidence before doing this role play } \\
\text { exercise? }\end{array}$ & $\begin{array}{l}\text { What knowledge and experience you } \\
\text { have gain from this audit supervisor role } \\
\text { play exercise? }\end{array}$ \\
\hline 1 & $\begin{array}{l}\text { "My confidence before doing this role play } \\
\text { exercise is about less than } 50 \% \text {.... few } \\
\text { things that is still confusing to me ......." }\end{array}$ & $\begin{array}{l}\text { "The experience when review the audit } \\
\text { working paper is it highlights the } \\
\text { importance of the calculation and } \\
\text { presentation...."; ".... this enhances my } \\
\text { knowledge at the same time boost my self } \\
\text { confidence." }\end{array}$ \\
\hline 2 & “.... I have low confidence ...." & $\begin{array}{l}\text { ".... I can gain more knowledge...."; “...I } \\
\text { can share my confusion with my } \\
\text { classmate."; “... I have a confidence to } \\
\text { complete the group account ......" }\end{array}$ \\
\hline 3 & “.... I have low confidence ...." & $\begin{array}{l}\text { "... my knowledge on consolidation of } \\
\text { financial statements is increasing and re- } \\
\text { enforced."; "This motivates me to push } \\
\text { myself...."; "... I found some problem on } \\
\text { the presentation ......" }\end{array}$ \\
\hline 4 & $\begin{array}{llr}\text { ".... basic } & \text { knowledge } & \text { on } \\
\text { consolidation/group account ....."; "My } \\
\text { confidence where I can rate over } 10 \text { is } \\
8 / 10 "\end{array}$ & $\begin{array}{l}\text { ".... knowledge gain from my } \\
\text { peer/colleague."; “.... self confidence in } \\
\text { this topic increase ........." }\end{array}$ \\
\hline 5 & ".... my knowledge .... is average ......" & $\begin{array}{l}\text { ".... achieve knowledge gain by myself and } \\
\text { through colleague explanation."; ".... } \\
\text { learn about technical accuracy and } \\
\text { presentation suitability ........." }\end{array}$ \\
\hline 6 & $\begin{array}{l}\text { ".... sometimes I still encounter problems } \\
\text { when doing consolidated accounts." }\end{array}$ & $\begin{array}{l}\text { ".... realised my knowledge was not } \\
\text { enough that it prompted me to learn } \\
\text { more of group account."; ".... I have } \\
\text { improved in certain areas ...... after } \\
\text { discussing the topic with my peers." }\end{array}$ \\
\hline 7 & $\begin{array}{l}\text { ".... not really know how to complete } \\
\text { consolidated financial statements ......" }\end{array}$ & $\begin{array}{l}\text { ".... my self confidence in preparation of } \\
\text { group account is unstable because so } \\
\text { many questions arises ........; ".... It }\end{array}$ \\
\hline
\end{tabular}




\begin{tabular}{|c|c|c|}
\hline & & $\begin{array}{l}\text { encourages me to do group discussion } \\
\text {....." }\end{array}$ \\
\hline 8 & $\begin{array}{l}\text { ".... difficult for me to prepare consolidated } \\
\text { statement of financial position." }\end{array}$ & $\begin{array}{l}\text { "... I learnt a lot through this activity } \\
\text {......."; "I questioned myself a lot of things } \\
\text { pertains to group account."; "I just } \\
\text { realised I still don't know about a lot of } \\
\text { things for this topic." }\end{array}$ \\
\hline 9 & $\begin{array}{l}\text { "My confidence before doing this role play } \\
\text { exercise is low ....." }\end{array}$ & $\begin{array}{l}\text { "...... errors could potentially lower the } \\
\text { accuracy of work produced."; “... } \\
\text { technical accuracy, presentation } \\
\text { suitability, and language are important } \\
\text {...." }\end{array}$ \\
\hline 10 & $\begin{array}{l}\text { ".... I feel I am not really confident to do } \\
\text { group accounting ......." }\end{array}$ & $\begin{array}{l}\text { "...... the layout of working paper is } \\
\text { important ........"; "I have gain a little bit } \\
\text { confidence ...." }\end{array}$ \\
\hline 11 & $\begin{array}{l}\text { ".... I have surface knowledge with lack of } \\
\text { deep understanding of the whole concept } \\
\text {......."; "My confidence towards the group } \\
\text { account is not so high ..........." }\end{array}$ & $\begin{array}{l}\text { "...... gained confidence ......... through } \\
\text { discussion with my colleague, ......"; “.... } \\
\text { enhanced my understanding towards the } \\
\text { concept, and alleviated my confidence } \\
\text {........" }\end{array}$ \\
\hline 12 & $\begin{array}{l}\text { "... I am not confident in preparing } \\
\text { consolidated financial statements." }\end{array}$ & $\begin{array}{l}\text { "...... the importance of technical accuracy } \\
\text {......"; "I am more confident in preparing } \\
\text { group account ...." }\end{array}$ \\
\hline 13 & $\begin{array}{l}\text { ".... limited knowledge about the group } \\
\text { account ......" }\end{array}$ & $\begin{array}{l}\text { ".... help me to have more confidence } \\
\text {....." }\end{array}$ \\
\hline 14 & $\begin{array}{l}\text { ".... my knowledge and confidence on this } \\
\text { consolidation/group account is limited } \\
\text {....." }\end{array}$ & $\begin{array}{l}\text { "I have learned that there are more than } \\
\text { just one way to present or calculate } \\
\text { goodwill ......."; ".... More suitable way to } \\
\text { present the working ......." }\end{array}$ \\
\hline 15 & $\begin{array}{l}\text { ".... I only managed to have a grip on the } \\
\text { theoretical aspects of consolidations ......" }\end{array}$ & $\begin{array}{l}\text { "... enabled me to understand the } \\
\text { procedures better and with more } \\
\text { confidence." }\end{array}$ \\
\hline 16 & $\begin{array}{l}\text { ".... learnt some basic knowledge about the } \\
\text { consolidation account ....."; "The } \\
\text { confidence in consolidation account is low, } \\
\text {......" }\end{array}$ & $\begin{array}{l}\text { ".... technical accuracy is important ......"; } \\
\text { presentation of the information required } \\
\text { and the language understandability are } \\
\text { important ....."; ".... increase in my self } \\
\text { confidence ......." }\end{array}$ \\
\hline 17 & $\begin{array}{l}\text { ".... I have some basic knowledge about } \\
\text { group account ....." }\end{array}$ & $\begin{array}{l}\text { ".... gain knowledge in more details .... as } \\
\text { we were able to discuss with our friends } \\
\text {....." }\end{array}$ \\
\hline 18 & $\begin{array}{l}\text { ".... I have basic understanding } \\
\text { consolidation account from class learning } \\
\ldots . . "\end{array}$ & $\begin{array}{l}\text { "I can apply my technical skill .... improve } \\
\text { my understanding ......" }\end{array}$ \\
\hline 19 & $\begin{array}{l}\text { ".... elementary knowledge about } \\
\text { consolidation account ....." }\end{array}$ & $\begin{array}{l}\text { "..... it enhance my understanding with } \\
\text { regards to goodwill on consolidation"; "... } \\
\text { able to apply my technical skill ..... has } \\
\text { increase my self confidence ....." }\end{array}$ \\
\hline
\end{tabular}




\begin{tabular}{|c|l|l|l|}
\hline 20 & $\begin{array}{l}\text { "... basic knowledge about group } \\
\text { accounting ....." }\end{array}$ & $\begin{array}{l}\text { "... able to apply the knowledge and skills } \\
\text { that I have gained from class." }\end{array}$ \\
\hline
\end{tabular}

Nine respondents in Group B playing the role of audit supervisor has indicated that they have either basic, surface, limited or elementary knowledge about group accounting. One respondent has an average knowledge, one respondent doesn't really know how to complete consolidated financial statement and one respondent faced difficulties in preparing consolidated statement of financial position. Five out of nine respondents found they learn something from this role-play exercise, where two of them found they gain more detailed knowledge through peer discussions, one of them learned that there is more than one way to compute goodwill, and three of them experienced improving and enhancing their understanding about the topic. Similarly, the respondent who has average knowledge also gain some knowledge through colleague explanation, where the respondent faced difficulties in preparing consolidated statement of financial statement learn a lot through this role-play activity. However, the other respondent who don't really know how to complete consolidated financial statement found this exercise does not help him much.

There are seven students in group B who have either low, not really, not, or limited confidence in preparing consolidation accounts before doing this exercise. On the other hand, one student has average level of confidence. Four out of seven students experienced their level of confidence improved after doing this role play, and one student found this exercise motivated him. Likewise, the student with average confidence also experienced increase in his confidence level.

Beside improving student knowledge and confidence in preparing group account, this roleplay pushed students to reflection on the importance of information presentation (by three students), technical accuracy (by three students) and language clarity (by two students). It also allowed two students to reflect that they are able to apply the skills that they have learn from class.

Collectively, majority of the students in this group experience some learning, either in improving the knowledge or/and confidence in preparation of consolidated accounts. Likewise, this role-play activity has open up for the students to reflection on information presentation, technical accuracy and language understandability, and application of skills from their prior learnings.

The results combination of both roles in audit associate and supervisor suggests that roleplaying offered students with learning opportunities in financial reporting, specifically in the preparation of consolidation accounts in the context of auditing. It also encouraged students to reflect the practical financial reporting issues within auditing scenario. Thus, these results infer role-playing model is an engaging tool in delivering undergraduate accounting study, specifically financial reporting.

\section{Evaluation of Role-Play Activities (by students)}

The students were very keen to give their comments and feedback about the role-play activity that they are involved. The evaluation of the exercise was conducted after the role-play exercise through google form with few basic questions related to their experience of the 
exercise. Out of 65 students who participated in the role-play, 50 students completed the survey. The survey involved likert scale with strongly disagree for score of 1 and strongly agree for score of 5 , and other comments are in qualitative manners. Tables 7 and 8 gives a snapshot of the experience that they felt.

Table 7: Summary of students' role-play experience

\begin{tabular}{|l|c|}
\hline Questions & $\begin{array}{c}\text { Average } \\
\text { feedback } \\
\text { score }\end{array}$ \\
\hline $\begin{array}{l}\text { Doing this role play exercise/activity helped me to better connect } \\
\text { to what I am learning in my class. }\end{array}$ & 4.24 \\
\hline $\begin{array}{l}\text { Completing this role play exercise/activity allowed me to re- } \\
\text { enforce my knowledge that I have learn in my class. }\end{array}$ & 4.32 \\
\hline $\begin{array}{l}\text { Completing this role play exercise/activity allowed me to } \\
\text { experience learning with my peers (eg. friend). }\end{array}$ & 4.42 \\
\hline $\begin{array}{l}\text { This this role play exercise/activity allowed me to think further of } \\
\text { my future the practical work expectation. }\end{array}$ & 4.14 \\
\hline $\begin{array}{l}\text { This this role play exercise/activity allowed me to understand } \\
\text { better the role of auditor (either audit associate/assistant or audit } \\
\text { supervisor) in the context of public practice (audit firm } \\
\text { environment). }\end{array}$ & 4.41 \\
\hline $\begin{array}{l}\text { I wish my other courses included role play exercise/activity } \\
\text { opportunities. }\end{array}$ & 4.32 \\
\hline
\end{tabular}

"Based on the scale : 1 for "strongly disagree" and 5 for "strongly agree"

Table 8: Qualitative comments on the students' role-play experience

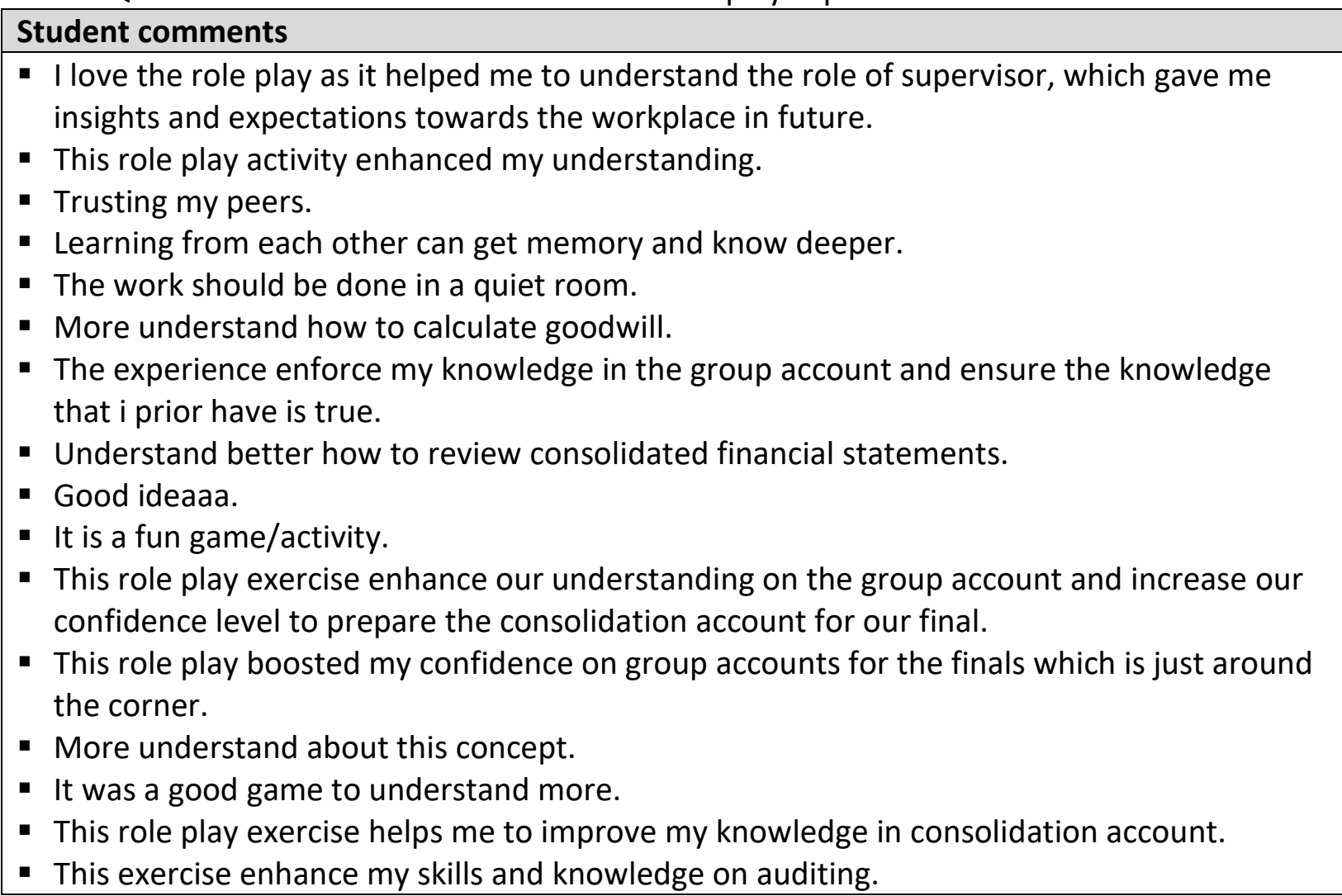


- Playing the audit supervisor roles allows me to detect any difference between my understanding and my friend understanding which has help me to learn more.

- Make the exercise longer.

- Learn how to detect an error.

- From this role play exercise, I'm able to learn about the consolidation in more detail. Moreover, from this role play exercise I could identify the particular areas that I'm weak.

- From this role-play activity it gave me better understanding on how consolidation account works in the real life.

- I don't like to write reflection.

- The role play allows me to share and exchange information with my peers in understanding more about the group accounts.

- People must have knowledge before engaging in the role play.

- Increase my knowledge on group account concept.

- This role play activity helped me to re-enforce my knowledge about group account.

- Do more on this activity in class to gain interest of student.

- More practical.

- The role play is very effective.

- Good.

- Give more questions.

- It helped to improve my understanding on consolidated financial statements.

- It was good experience and fun to be play around with classmate i mean at least we got the chance to ask around since this is not my batch hence I don't really know my junior by doing this activity we can study and ask each other.

- I would prefer to do the questions during class time in which I could ask when I can't solve the question.

- Fun. Hope will be implemented regularly.

- The role play help me to have better understanding in real working situation.

- Good experience.

Based on the feedback shown in Table 7, the scores range from 4.14 (82.8\%) to $4.42(88.4 \%)$. The indicate students are pleased with the learning from this role-play exercise. The feedback scores concur with most of the qualitative comments in Table 8 where students expressed their love for this exercise, having fun with this activity, asking for longer and more role-play exercise, allowed them to share and exchange information with their peers. Students also learned trusting with their peers, enhancing knowledge in auditing, and identifying errors. Beside the positive feedbacks, few students give other comments like they don't like writing reflection and the exercise does not allow them to ask for more close guidance for the question's problem.

\section{Conclusions}

Finding innovative ways in engaging tertiary students in learning accounting will impact their future endeavour in practical accounting world. Role-playing is an experience-based learning technique designed to allowed students to achieve the intended learning objectives. They took the roles as audit associate and audit supervisor to mimic the scenario of an audit firm. Despite students are playing differing roles, but it allowed them to have different exposures for the role that they are in, as part of financial report preparation. Group A played the role of audit associate has recorded some experienced in knowledge and confidence improvement 
in preparing consolidation accounts (financial reporting), with reflecting on auditing issues like audit evidence and preparation of audit working paper. Likewise, Group B who role play the position of audit supervisor also documented some learning in knowledge and increase in confidence in preparing group accounts (financial reporting), with the reflections the importance of quality audit working paper in the perspectives of information presentation, technical accuracy and language clarity. This research shows that role-playing in financial reporting in the context of auditing scenario has offered students with variety of learning opportunities. Researcher suggests that role-play model can be applied to other accounting learning activities with inter-related subjects within accounting.

\section{Acknowledgement}

This study was wholly funded via the Scholarship of Teaching and Learning Grant SoTL(A)/FEP/2019(2)/019 from Universiti Malaysia Sarawak (UNIMAS).

\section{References}

ACCA. (2018). ACCA Malaysia: Empowering Women, Accountants Today, Malaysian Institute of Accountants, Jul-Aug 2020 Ed., https://www.atmia.my/2018/08/01/acca-malaysia-empowering-women/

Apostolou, B., Dorminey, J. W., Hassell, J. M., \& Rebelee, J. E. (2017). Analysis of trends in the accounting education literature (1997-2016), Journal of Accounting Education (article in press)

Boyce, G. (2004). Critical Accounting Education: Teaching and Learning Outside the Circle, Critical Perspectives on Accounting, 15(4), 565-586

Buckhaults, J., \& Fisher, D. (2011). Trends in Accounting Education: Decreasing Accounting Anxiety and Promoting New Methods, Journal of Education for Business, 86(1), 3135

Craig, R., \& Amernic, J. (1994). Roleplaying in a Conflict Resolution Setting: Description and Some Implications for Accounting, Issues in Accounting Education, Sarasota, 9(1), Spring 1994, 1-19

de Araujo, A. M. P., \& Slamski, V. G. (2013). Active Learning Methods - An Analysis of Applications and Experiences in Brazilian Accounting Teaching, Creative Education, 4(12B), 20-27

Hui, F. \& Koplin, M. (2011). The Implementation of Authentic Activities for Learning: A Case Study in Finance Education, e-Journal of Business Education \& Scholarship of Teaching, 5(1), 59-72

Husnin, H., Din, R., Karim, A., Norman, H. \& Hamdan, A. (2013). Assessing Authentic Learning via Storyboarding: A Malaysian Perspective, Asian Social Science, 9(16), 4653

Kilgour, P., Reynaud, D., Northcote, M. T., \& Shields, M. (2015). Role-playing as a tool to facilitate learning, self-reflection and social awareness in teacher education. International Journal of Innovative Interdisciplinary Research, 2(4), 8-20

Lombardi, M. M. (2007). Authentic Learning for the 21st Century: An Overview, EDUCAUSE Learning Initiative, ELI Paper 1 (2007), 1-12

Ministry of Education Malaysia. (2015). Executive Summary - Malaysia Education Blueprint 2015-2025 (Higher Education), 1-31 
Neo, M., Neo, K. T-K., \& Tan, H., Y-J. (2012). Applying Authentic Learning Strategies in a Multimedia and Web Learning Environment: Malaysian Students' Perspective, The Turkish Online Journal of Educational Technology - July 2012, 11(3), 50-60.

O'Callaghan, S., Elson R. J., \& Walker J. P. (2012). Using Role Play as an Experiential Learning Tool to Introduce Students to Auditing, ABD Journal, 4(2), 1-22.

Rule, A. C. (2006). Editorial: The Components of Authentic Learning, Journal of Authentic Learning, 3(1), 1-10.

Samkin, G., \& Stainbank, L. (2016). Teaching and Learning Current and Future Challenges Facing Accounting Academics, Academics, and the Development of an Agenda for Future Research, Meditari Accountancy Research, 24(3), 294-317

Saptono, L. (2010). The Implementation of Role-Playing Model in Principles of Finance Accounting Learning to Improve Students' Enjoyment and Students' Test Scores, Jurnal Akuntasi dan Keuangan, 12(2), 71-81

Tan, H. Y-J., Neo, M., Neo, T. K., Kwok, W. J., Lee, K., W., \& Lai, C. H. (2014). Developing Creative and Critical Thinking Skills in an Authentic Learning Environment, Jurnal Teknologi (Sciences \& Engineering), UTM, 68(2), 1-12

Tan, H., Y-J. \& Neo, M. (2015). Exploring the Use of Authentic Learning Strategies in Designing Blended Learning Environments: A Malaysian Experience, Journal of Science \& Technology Policy Management, 6(2), 127-142

Toh, C. H., Yeap, M. C., Gooi, P. H. \& Ismail, S. A. M. M. (2012). Incorporating the Authentic Learning Approach in an Adult Learners Classroom at a Public University in Malaysia, International Journal of Arts \& Sciences, 5(3), 281-288

Zandi, G., Naysary, B., \& Kwan, S. S. (2013). The Behavioral Intention of Malaysian Students Toward Accounting Discipline, Accounting and Management Information Systems, 12(3), 471-488 